\title{
Erratum to: A new paradigm of DNA synthesis: three-metal-ion catalysis
}

Wei Yang ${ }^{*}$ (D, Peter J. Weng and Yang Gao

\section{Erratum to: Cell Biosci (2016) 6:51}

\section{DOI 10.1186/s13578-016-0118-2}

Upon publication of the original article [1], it was noticed that the Fig. 2 is incorrect. This has now been acknowledged and corrected in this erratum. The correct Fig. 2 has been shown below.

\section{a}

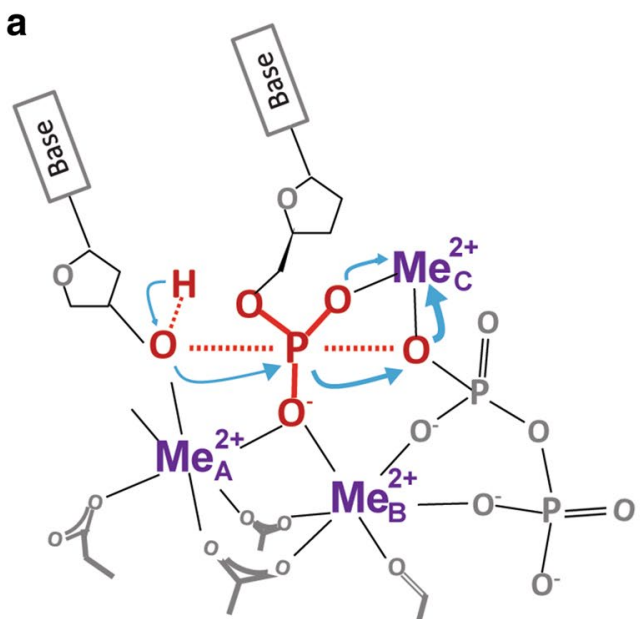

b

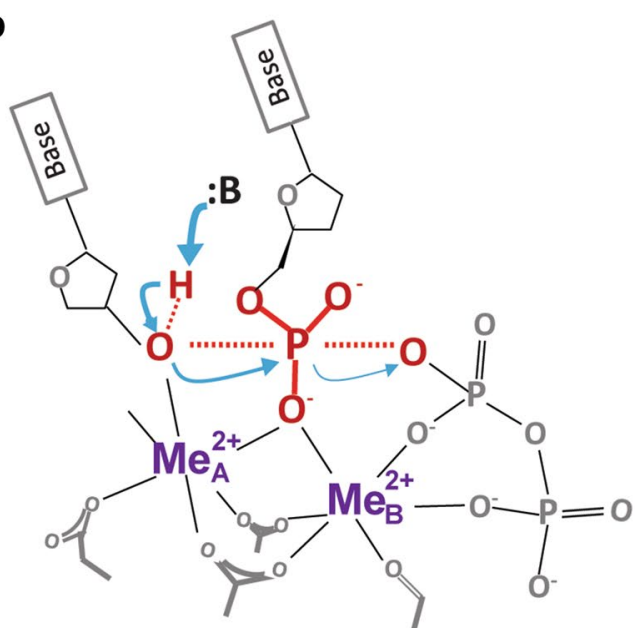

Fig. 2 Comparison of the initiation of phosphoryltransfer in two-versus three-metal-ion catalysis. a In three-metal-ion catalysis, the C-site metal ion initiates the reaction by breaking the existing phosphodiester bond in dNTP and thus drives the phosphoryltransfer reaction. A well-aligned native $3^{\prime}-\mathrm{OH}$ is required for capture of the C-site metal ion and its deprotonation is a result of the reaction. $\mathbf{b}$ In two-metal-ion catalysis, the reaction starts by de-protonation of the $3^{\prime}-\mathrm{OH}$ (nucleophile), which activates nucleophilic attack and leads to breakage of the existing phosphodiester bond in dNTP

*Correspondence: wei.yang@nih.gov

Laboratory of Molecular Biology, NIDDK, National Institutes of Health,

9000 Rockville Pike, Bethesda, MD 20892, USA provided you give appropriate credit to the original author(s) and the source, provide a link to the Creative Commons license, and indicate if changes were made. The Creative Commons Public Domain Dedication waiver (http://creativecommons.org/ publicdomain/zero/1.0/) applies to the data made available in this article, unless otherwise stated. 
The online version of the original article can be found under doi:10.1186/s13578-016-0118-2.

\section{Publisher's Note}

Springer Nature remains neutral with regard to jurisdictional claims in published maps and institutional affiliations.
Received: 15 June 2017 Accepted: 15 June 2017

Published online: 20 June 2017

Reference

1. Yang W, Weng PJ, Gao Y. A new paradigm of DNA synthesis: three-metalion catalysis. Cell Biosci. 2016;6(1):51. doi:10.1186/s13578-016-0118-2. 